日臨外会誌 $60(12) ， 3317-3324 ， 1999$

症例

肺腺癌治瘉切除 13 年後に脳転移と肺転移を認め切除しえた 1 例

\author{
呪島中央病院外科"，国立岡山病院呼吸器外科" ${ }^{2}$, \\ 香川医科大学第 2 病理 ${ }^{31}$ ，国立療盖所高松病院外科 \\ 坪田典 $2^{15)}$ 田邊秀幸" 東 良 ${ }^{23}$ \\ 桑原宏子“谷口清英”
}

肺癌術後 10 年以上を経ての再発は比較的稀である. 今回，術後 13 年後に孤立性脑転 移と孤立性肺転移が指摘され，切除しえた 1 例を経験したので報告する。症例は 74 歳。 1983 年 1 月前医で肺腺癌により右下染切除術 ( $\left.\mathrm{R}_{2}\right)$ 施行. p- T, N $\mathrm{N}_{0} \mathrm{M}_{0}$, IA 期, 絶対的治

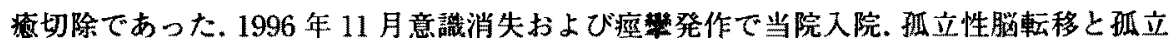
性肺転移が指摘され，共に外科的に切除しえた，病理所見から共に肺腺癌転移病変と診 断された，原発および脳・肺転移切除標本での增殖細胞核抗原（PCNA）と sialyl-Lewis $\mathrm{X}$ 糖鎖抗原 $\left(\mathrm{sLe}^{\mathrm{x}}\right)$ の発現についての免疫組織学的検討では, 全標本で強陽性の結果がえ られた．PCNA，sLe 陽性の場合には，術後長期にわたってのフォローの必要性が考え られた.

索引用語：肺癌再発, PCNA, sialyl-Lewis 抗原

緒 言

肺癌切除後の再発時期は約 $80 \%$ が 2 年以内とされ、 10 年以後の再発は稀と考えられている.今回，肺腺癌 治瘾切除後 13 年を経て孤立性脳転移と孤立性肺転移 の再発を認め切除しえた1例を経験したので報告す ๖.

患者：74 歲，女性.

$$
\text { 症例 }
$$

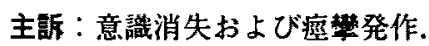

既往歴・現病歴：1983（昭和 58）年 1 月 7 日, 前医 で集検発見による右肺下葉 $\mathrm{S}^{9}$ の肺癌に対して右下葉 切除術十程隔リンパ節郭清術施行. 腫場は $2.0 \times 1.8 \times$ $1.7 \mathrm{~cm}$ 大.

術後病理診断：中分化型腺癌 (乳頭型)， $\mathrm{p}-\mathrm{T}_{i} \mathrm{~N}_{0} \mathrm{M}_{0}$, Stage IA, 絶対的治痊切除であった.この肺㿋切除標本 H.E 染色像を図 1 左上および図 2 左上に示す，粘液産 生の豊富な腺癌像である。術後，エスキノン $2 \mathrm{mg}+5$ FU $250 \mathrm{mg}+$ キロサイド $20 \mathrm{mg}$ による化学㙩法を 2 クール/週 $\times 5$ 週（計 10 クール）施行された。

この前医で術後外来フォローを1994（平成 6）年 5 月9日までされており,この時点で胸部単純 X 線や腫

1998 年 9 月 24 日受付 1999 年 9 月 9 日操用

'現：国立療姜所高松病院外科
瘍マーカーに異常は認められなかったとのことであっ た.

今回 1996（平成 8）年11月19日意識消失および痤

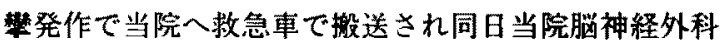

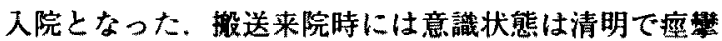
も認めなかった。

入院時現症：体格中等度，栄養状態良好。意識は清 明，頭痛なし，嘔気・显吐なし，麻掼症状認めず，神 経学的所見も正常. 血压 146/90 $\mathrm{mmHg}$, 脈拍 84 /分. 整．軽度の負血認めるも，黄㾝なし．

入院時血液换查所見: 白血球数 $6,500 / \mu \mathrm{l}$, 赤血球数 $340 \times 10^{4} / \mu \mathrm{l}, \mathrm{Hb}$ 值 $10.3 \mathrm{~g} / \mathrm{dl}$, Ht 值 $29.7 \%$, 血小板数 $26.6 \times 10^{4} / \mu \mathrm{l}$, 軽度の筫血を認めた。血液生化学検查に おいては，異常值は認めなかった。腫場マーカ一 (CEA, NSE, TPA，SLX)は正常筙用内であっだ.

頭部 CT 造影検查 (図 3 左)，頭部 MRI 造影検查(図 3 右：Gd-DTPA， $T_{1}$ 強調像)：入院時の頭部CT お よびMRI 検査では，左前頭葉に径 $3 \mathrm{~cm}$ 大の孤立性で 一部に造影陽性の充寒性成分を含む咅胞栏の腫瘤を認 めた。

胸部単純 X 線（図 4）：右肺野は下葉切除のために 容量減少し術後変化を呈していた。この胸部単純 X 線には明らかな異常影は指摘できなかった。 

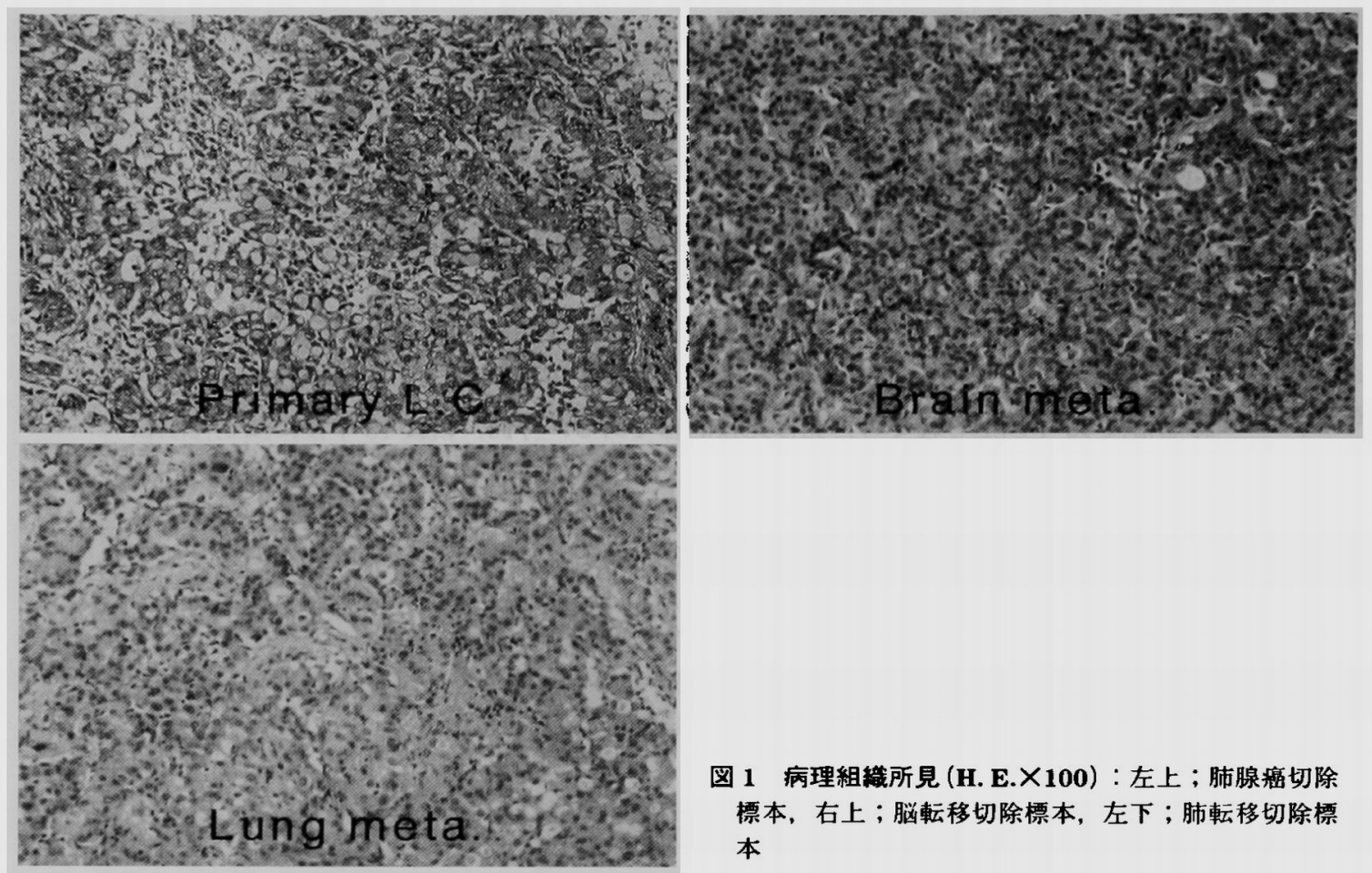

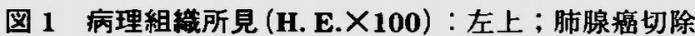
標本, 右上; 脳転移切除標本, 左下 ; 肺転移切除標 本
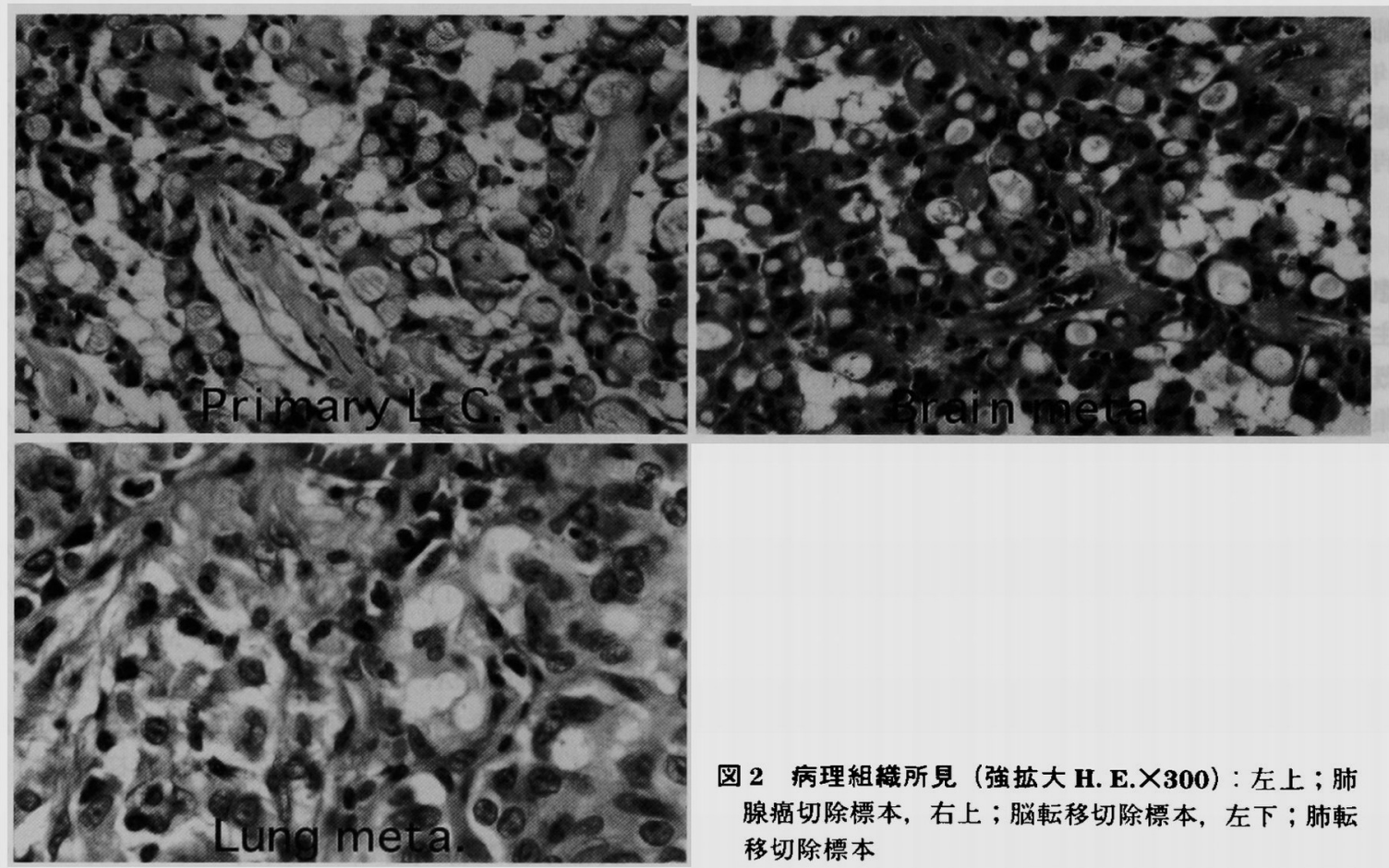

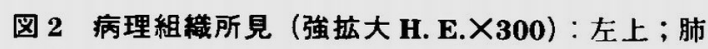
腺癌切除標本, 右上; 脳転移切除標本, 左下; 肺転 移切除標本 
胸部 CT 検查（図 5)：右残存肺の内，右.上葉後外側 に径 7〜8 mm 大の辺縁境界明暸な結節影を認めた。程 降, 肺門リンパ節腫脹や胸水は認めなかった.

腹部 CT, 腹部超音波検査：異常所見は認められな かった.

入院後の経過：以上の諸検査により，脳腫瘍につい ては肺癌術後の脳転移再発が最も疑われた. 右残存肺 に認められた結節影についても肺癌転移再発が考えら れた．その他の全身検索で転移もしくは異常と考えら れる所見は認めなかった. そこで，今回指摘された脳 腫惶はその大きさもさることながら，最も予後に影響 すると考えられたため，準毉急的に脳腫瘍の摘出手術 を行う必要があると判断, 肺腫場については脳腫瘍摘 出後の病理診断や術後の経過をみて精查すべきと考え た.

平成 8 年 11 月 21 日当院脳神経外科により開頭下に 脳腫瘍摘出術を施行した。術後病理標本検査では, goblet cell を有する低分化な adenocarcinoma であった。 図 1 右上および図 2 右上にその H. E. 染色像を示す. このような腺癌は原発性脳腫漡としては考え難く、転 移性病変と考えられた。その結果, 图 1 左上および図 2 左上に示した 13 年前の肺腺癌切除病理標本との類 似性から肺癌脳転移と考えるのが最も妥当と診断し た. 術後は順調に回復, 転移性脳腫瘍については外科 的切除のみで経過をフォローした．転移性脳腫瘍術後 約 1 年経過した平成 9 年 10 月に入り, 頭部を含め全身 検索を施行した. 頭部 CT や頭部 MRI では頭蓋内再発
は認めなかった. 胸部 CT でも入院時と著変なく,指摘 されていた右残存肺の孤立性結節影に明らかな増大は 認めなかった．腹部 CT や腹部超音波検査でも異常所 見は認めなかった．腫湯マーカーも正常範囲内であっ た. 胸部 CT での孤立性結節影については, 肺転移の疑 いは否定できないため, 確定診断のために平成 9 年 10 月 20 日右肺部分切除術を施行した.この病理組織検査 では脳転移病巣と同梯で, goblet cell を有する低分化 な adenocarcinoma であった. またこの病理所見では, 画像所見と同じく辺縁境界は明瞭で, 結節状に膨張性 增殖を示していた，腫場辺緑部における既存の肺胞壁 に沿った腫場細胞の乳頭状增殖像は認められなかっ た.ささらに腫場中心部では結節内に壊死巣は認められ たが, 線維化巣や般痕収縮像は認められず, 腫堭周囲 の血管, 気管支, 胸膜の腫場に向かっての集束像も認 められなかった。これらは原発性病変よりも転移性病 変を支持するものであった. 図 1 左下および図 2 左下 にその H.E. 染色像を示す. 以上より右残存肺結節影 も肺転移と診断された. 平成 10 年 9 月現在, 再発の徴 候なく健在である.

免疫組識学的検査 : 肺腺癌切除標本, 脳転移切除標 本, 肺転移切除標本のパラフィン包埋ブロックから, それぞれの增殖細胞核抗原 (proliferating cell nuclear antigen, 以下 PCNA)の免疫染色による PCNA 陽性率 の検討と, sialyl-Lewis X 糖鎖抗原の免疫染色による同 抗原の発現の検討を行った. PCNA 染色像をそれぞれ 图 6 に示す（図6 左上：肺腺癌切除標本, 図 6 右上：

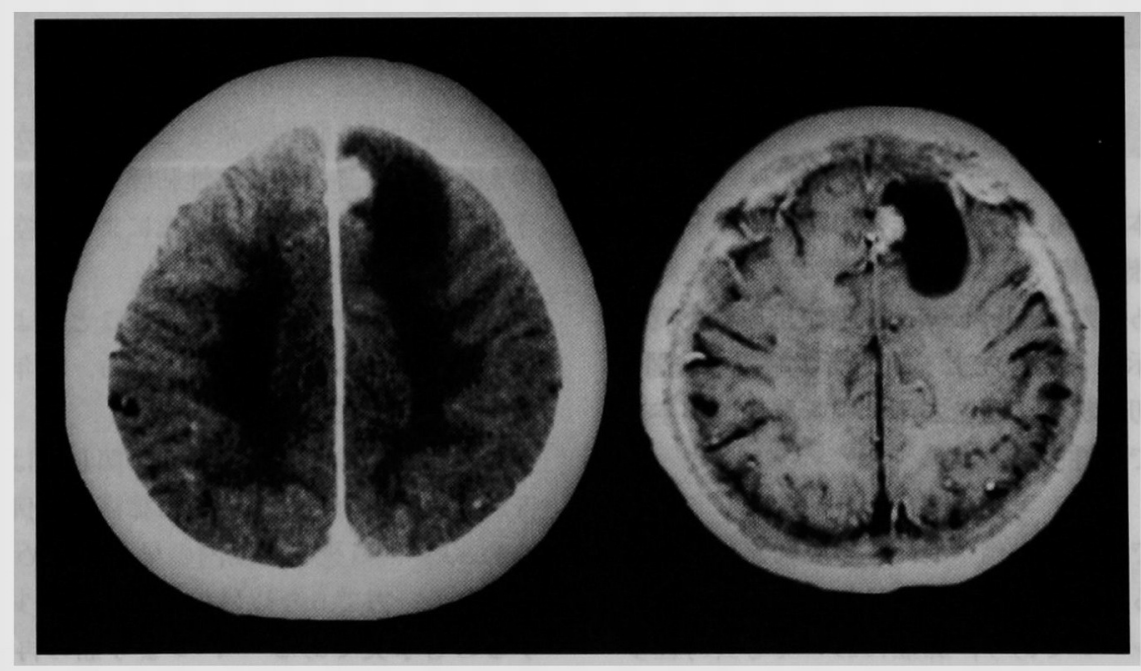

図 3 左; 頭部 CT (造影), 右 ; 頭部 MRI (Gd-DTPA 造影, T 1 強調像). 


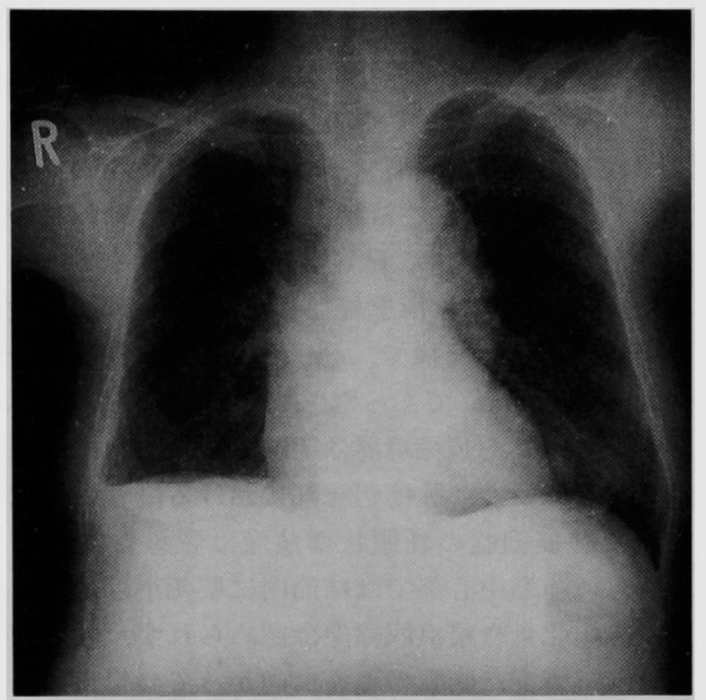

図 4 胸部単純 $\mathbf{X}$ 線

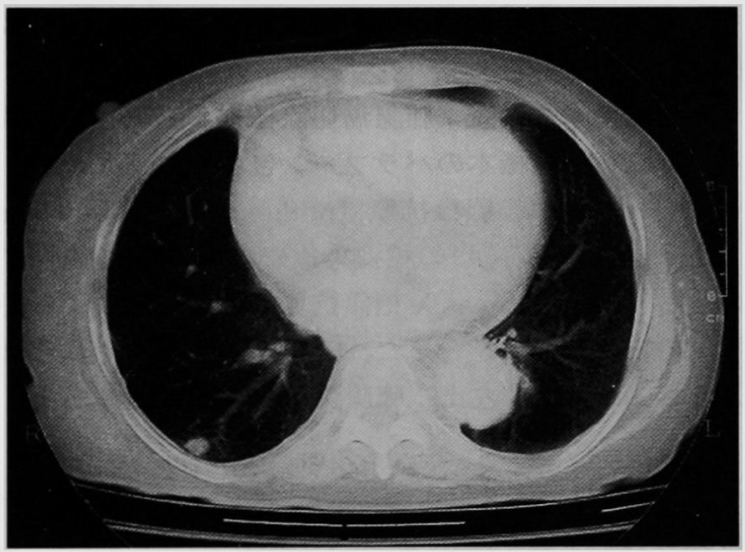

図 5 胸部 CT

脳転移切除標本, 図 6 左下：肺転移切除標本). PCNA 陽性率は原発肺腺癌：52.5\%, 脳転移：38.4\%, 肺転 移： $84.2 \%$ であった. sialyl-Lewis X 糖鎖抗原の免疫染 色像を図 7 に示す（図 7 左上：肺腺癌切除標本，図 7 右上：脳転移切除標本, 図 7 左下：肺転移切除標本). すべての標本で陽性であった。

\section{考察}

再発の診断では，第二癌（異時性多発肺癌）との鑑 別が問題となる。癌治療後の患者は第二癌，第三癌の ハイリスクグループであり，肺癌においても異時性多 発癌の温床となりうると考えられているからである.
Martini ら"は，異時性多発肺癌の条件として，組織 型が同一の場合, (1)第一癌と第二癌の間隔が 2 年以上, (2)第二癌が carcinoma in situ からの発生である. (3)第 二癌が異なった肺葉に存在し，かつ共通のリンパ節転 移や多臓器転移がないことを挙げている。しかし現在 では 2 年以後の再発も存在するとの考え方から, 臨床 経過や病理組織学的所見を総合して判断, 鑑別するの が一般的と考えられている. 実際, 組織型が同一の場 合には再発か多発癌かの正確な鑑別は困難であり, 今 後の遺伝子学的診断などの進歩が期待されているのが 現状といえる.今回の症例でも，13 年という長い経過 であり，肺転移巣が第二癌ではないのか，また脳転移 が今回の肺病巣からの転移ではないのかが問題となっ た。しかしながら特に肺病変において，(1)病理組織学 的にともに粘液産生の豊富な腺癌で組織学的類似性が 高いこと. (2)肺病巣の画像所見において spicula や notch, pleural indentationを伴わない境界明暸な結 節影であり，肺血管や気管支の関与も認めない点. (3) 肺病変の切除標本病理所見においても辺縁境界は明瞭 であり結節状に拡大性の増大を示し，腫瘍辺縁部にお ける既存の肺胞壁に沿った腫瘍細胞の乳頭状増殖像は 認められなかった. (4)原発性肺腺癌で認められるよう な腫瘍の中心部での間質性の線維化部分や痗痕収縮像 は認められず，その結果生ずると考えられる腫瘍周囲 の血管，気管支，胸膜が腫瘍に向かって集束する像も 認めなかった，以上から肺病変については原発性肺癌 としての第二癌よりも肺転移病変とするのが妥当と判 断した。なお，転移巣内に壊死巣も観察された。一般 に原発性肺腺癌では腫瘍内における壊死は少ないとさ れる. 但し低分化型腺癌では高分化型に比べ壊死巣の 頻度は高くなるとされ, 今回の壊死巣は転移病変とし てより低分化な腺癌病巣としての特徴が現れたものと 考えられた。また，転移性肺腫瘍において本症例のよ うな結節型のものでは，壊死によって空洞化すること もあるとされている。

肺病変が転移巣と診断されたことにより，脳転移病 巣も臨床経過および病理所見から，13 年前の肺癌から の転移と診断した。

肺癌の再発様式と再発時期に関しては多くの臨床報 告がなされている。一般的に肺癌切除例における再発 の約 $80 \%$ は術後 2 年以内の早期に認められるとされ る. その一方で 5 年以降の晚期再発も少数ながら存在

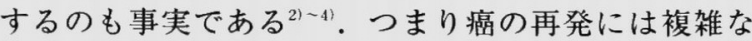
背景があると考えられている，もし肺癌手術後の再発 

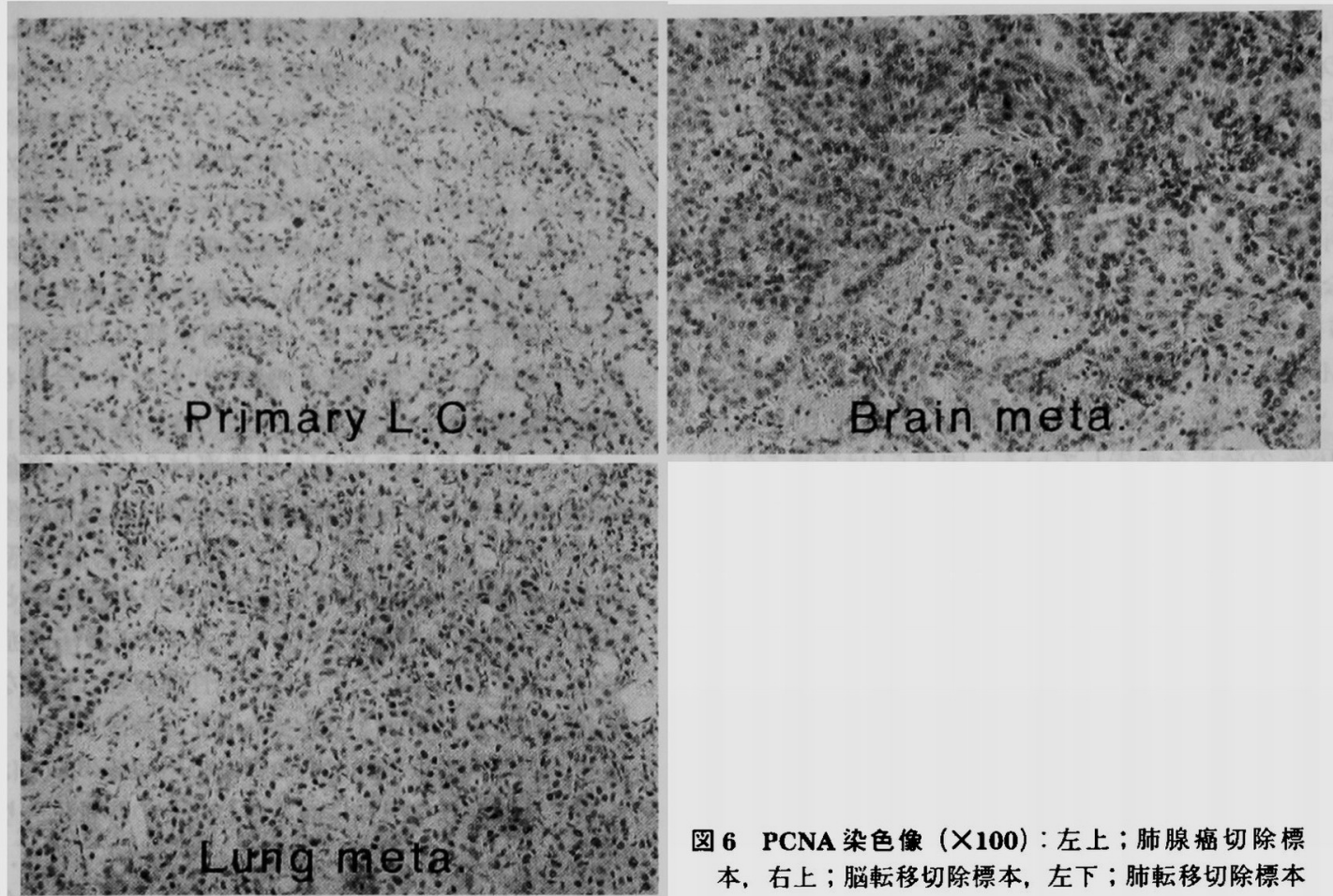

图 6 PCNA染色像 $(\times 100)$ : 左上; 肺腺癌切除標 本, 右上; 脳転移切除標本, 左下 ; 肺転移切除標本
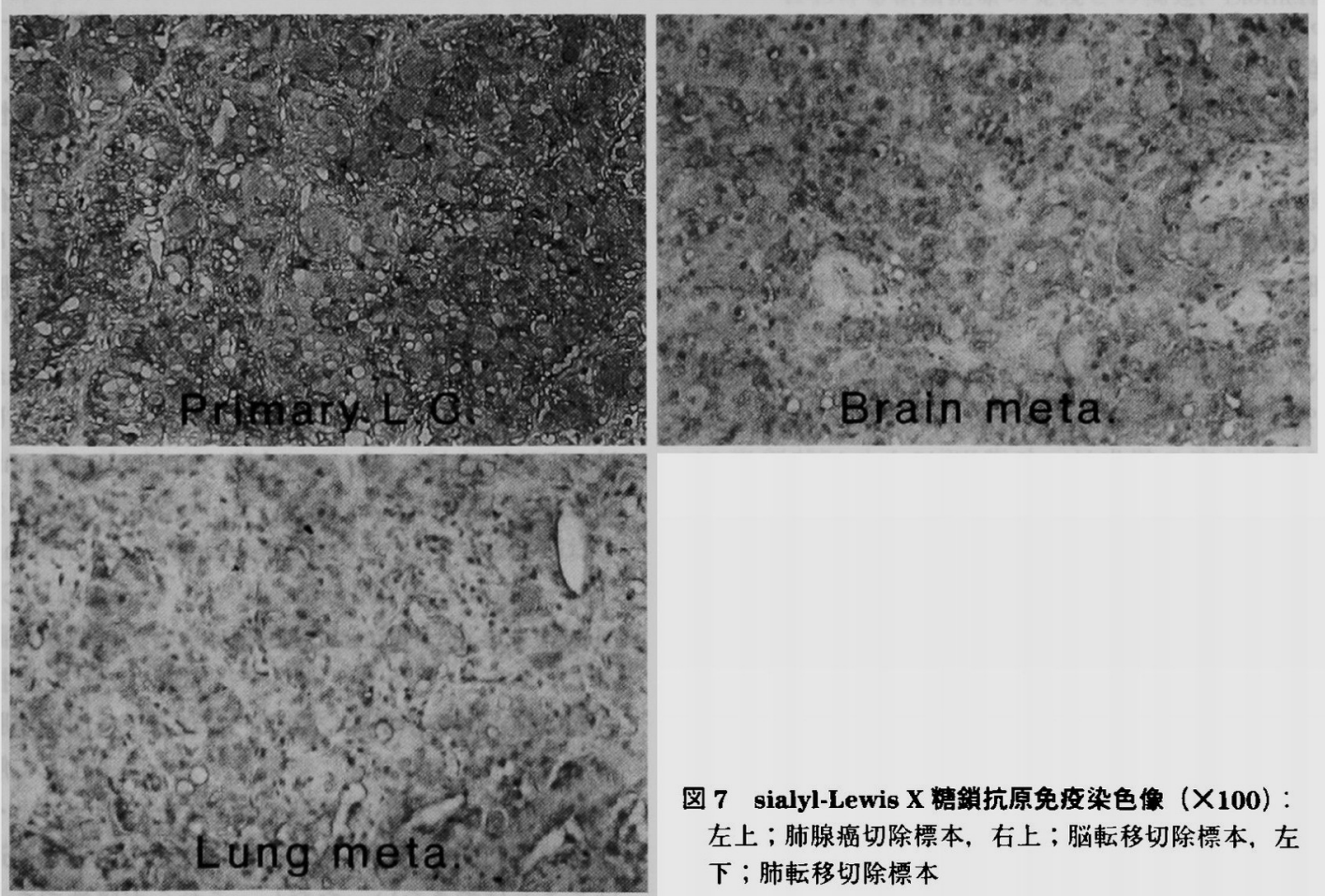

図 7 sialyl-Lewis $X$ 㮫鎖抗原免疫染色像 $(\times 100)$ :

左上; 肺腺癌切除標本, 右上; 脳転移切除標本, 左 下；肺転移切除標本 
が，道残した癌細胞の数・量に依存しているならば再 発の時期や病態はもっと単純なものである.しかし, 本症例のように術後長期を経ての再発が存在するよう に，遺残した癌細胞は色々と修飾された缩主内環境に あると考えられる，そのために術後早期に增殖すなわ ち再発する㿋細胞がある一方で, 見かけ上增殖するこ となく存続し一定期間経た後に增殖する晩期再発が存 在すると推定されている.

Mathisen ら $ら^{51}$ 術後 5 年生存例の $25 \%$ に再発肺㾝 ないし第二瘦の発症を、Temeck ら゙は術後 10 年以降 に16\%の発症を報告している．国島ら”は術後 5 年以 降の再発は腺癌で多いと報告しており, 当症例と合致 する。本例においては原発性肺腺澏術後 13 年目に脳転 移と肺転移が発見きれた訳であるが，それぞれが術後 のどの時点でCTなどの画像診断で発見できるレベル に達していたかは不明である。事実脳転移が症状発現 により発見されたことについて，それ以前に頭部 CT を実施してい机より早期の段階での発見が可能で あったと推察される。しかし実際問題として, 肺癌手 術後の外来での診療期間や検査方法・項目についての 明確な指針はないのが現状である。

そこで，本症例に扔ける腫瘍細胞の生物学的特性を 明らかにするために, 免疫組織化学的手法を用いて, 增殖細胞核抗原 (proliferating cell nuclear antigen, PCNA）の免疫染色によるPCNA 陽性率の検討と, silyl-Lewis X 糖鎖抗原の免疫染色による同抗原の発現 の検討を行った。

PCNAはG1期からS期の細胞の核に認められ增 殖細胞の指標とされ，癌での生物学的悪性度を表す マーカーの1つとされている . 腫湯細胞の增殖能を PCNA 陽性率で検討すると, 原発巣 $52.5 \%$, 脳転移单 $38.4 \%$ ，肺転移巣 $84.2 \%$ であった、肺腺厡における PCNA 陽性率の報告は，矢満田"によれば肺腺瘦 34 例で $12.3 \pm 9.2 \%$ ， 定の内訳は高分化型腺癌 23 例で 7.1 $+2.5 \%$ ，中分化型腺癌 11 例で $23.2 \pm 9.0 \%$ であった。 越川ら ${ }^{10}$ によれば, 腄癔径 $2 \mathrm{~cm}$ 以下の肺野末梢小型肺 腺癌 56 例の PCNA 陽性率は $28.3 \pm 18.7 \%$ (2.1\% 85.4 $\%$, 組織分化度別では高分化型 14 例：18.2 $11.3 \%$,


$19.8 \%$ と報告されている。

肺癌症例における PCNA 陽性率と予後については, 陽性率の高い方が予後がより不良とする報告が散見さ


值を示しており予後不良が予測された。しかしこれら
の報告では PCNA 高陽性で早期再発が多いとされ，本 症例とは合致しない。晚期再発例では PCNA 陽性率は 低かったとの報告 ${ }^{13}$ むられる。しかしながら，PCNA 高陽性症例では，再発のリスクが高いと考えるのが妥 当であり，長期にわたる注意深いフォローが必要であ ると考えられた。また脳転移病変と肺転移病変部の PCNA 陽性率も高值を示した。転移性腫境における PCNA 陽性率の検討でも，転移病変部の PCNA 陽性 率は予後因子となりうるとの報告(14)あり，今後も再 発の危险性は高いと考えている。

また，肺転移紧の PCNA 陽性率は $84.2 \%$ と高値に もかかわらず, 約 1 年の経過で肺病変の大きさに変化 を認めない点も注目された。われわれの検索では PCNA と腫瘍倍加時間といった腫演の增大速度との 関係を示す報告は認めなかった。しかしながら本症例 での肺転移は前述したように原発性肺腺癌とは異なる 拡大性の增殖バダーンであったことを考慮すれば，腫 場サイズの堌大は単純にその腫演の增殖能のみではな く宿主との複雑な関係にあることがその背景にあり， PCNAのみからの推定は困難であると考えられた.

一方, sialyl-Lewis X 糖鎖抗原は細胞接着蛋白セクレ チンファミリーの1つであり，癌細胞の転移における 血管内皮細胞に対する接着に関与すると考えられてい る. 特に肺腺癌での転移発現との関連が指摘され，い わゆる転移能の指標の1つとされている(5). 原発性肺 腺澏標本, 脳転移切除標本, 肺転移切除標本のいずれ においても腫場細胞の大部分で陽性所見を認め，他の 報告1516)の強陽性に相当する結果であった。つまり転 移発現をおこしやすいということを示しており，脳転 移や肺転移を来たした自験例と合致する。

肺癌の分子生物学的予後因子には PCNA や sialyl Lewis X 糖鎖抗原以外にも細胞增殖能マーカーとして は, DNA ploidy, Argyrophilic neucleolar organizer resions (AgNORs) などが，また転移能マーカーとし ては細胞外マトリックス分解の見地から，Urokinasetype plasminogen activator (uPA), Catepsin $\mathrm{B}(\mathrm{CB})$, Matrix metalloproteases (MMPs) などの多数が検討さ れている17181. しかしこれら予後因子のどれを選択す るかは種々問題があるにせよ，これら予後因子が肺癌 治療における生存期間に影響を与える因子として解析 されており，それらが陽性であることが今回のような 術後長期間を経ての再発の直接の原因や因子と関連づ けることはできない。ただし，これらが陽性であった 場合には再発の可能性が高いと推察され，つまり問題 
はその再発の危険性が術後長期にわたるかどうかであ るが,この点については今後の検討課題といえる.

肺癌術後のフォローにPCNA などの予後因子デー 夕を追加することは有用であり，予後不良と推定され る症例には長期にわたるCT 含めた追跡が必要と考 えるべきであろう．本症例においても，今後の再発の 可能性は十分考えられ，注意深い経過観察を要すると 思われた.

\section{結語}

I期肺腺癌治湴切除 13 年後に坬立性脳転移と孤立 性肺転移を認めた症例を経験し，共に切除しえたので PCNA と sialyl-Lewis X 楉鎖抗原についての兔疫組織 学的検討も加え報告した.

なお, 本論文の要旨は第 37 回日本肺癌学会中国四国地方 会（平成 10 年 7 月 3 日広島市）で発表した。

\section{文献}

1) Martini $N$, Melamed $M R$ : Multiple primary lung cancers. J Thorac Cardiovasc Surg $70: 606-612$, 1975

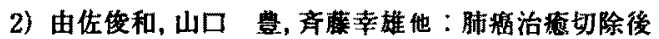
の再発に関する臨床的検討. 肺痁 $30: 209-215$. 1990

3）岡安揵至，長谷川直人，大久保哲之能：再発肺瘦の 病㦔と治痖. 外科 $52: 989-993,1990$

4）小松彦太郎, 片山 透, 村上国男他：肺嵒切除例の 再発部位の特徴とその対策. 日呼外会誌 4 ： 430-436, 1990

5) Mathisen DJ, Jensik RJ, Faber LP, et al : Survival following resection for second and third primary lung cancers. J Thorac Cardiovasc Surg $88: 502$. 1984

6) Temeck BK, Flehinger BJ, Martini N : A retrospective analysis of 10 year survivors from carci- noma of the lung. Cancer $53: 1405-1408,1984$

7) 国島和夫，高木 陶山元一他：肺瘁切除例にお ける再発の病態. 肺癌 $25: 329-334,1985$

8) Robbins BA, Vega D, Ogata K, et al : Immunohistochemical detection of proliferating cell nuclear antigen in solid human malignancies. Arch Pathol Lab Med 111 : 841-845. 1987

9）矢満田健：ヒト肺癌の增殖能と血管容積に関する 免疫組織学的研究. 信州医誌 42:547-560.1994

10）越川卓, 中村栄男, 鬼頍邦吉他：肺㾝と PCNA. 臨病理 94:113-124, 1994

11）藤井昌史, 元井 信, 恢伯英行地：非小維胞腑瘦切 除例における proliferating cell nuclear antigen $の$ 免疫組織学的検討. 癌の臨 $38: 1190-1194,1992$

12）小松彦太郎，宮島邦治、田村厚久他：肺㿋切除例の 捺印細胞標本を用いたPCNA および p 53 発现絜 と予後に関する検討. J Jpn Soc Clin Cytol 35： 517-523, 1996

13）矢满田键, 羽生田正行, 宮澤正久地：現在まで 12 年間の経過中，再発肺局にて計 3 回の肺切除を施

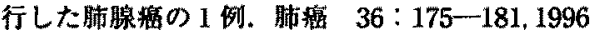

14）松島伸治, 山本英奇, 相田成隆地：転移性肺腫福に おける PCNA 陽性率と予後因子の評洒. J Jpn Soc Cancer Ther 30:1635-1640. 1995

15）矢满田健，羽生田正行，飯田 太他：七卜肺貔組䅧 における糖鎖抗原の発現との関連. Biotherapy $9: 1353-1358.1995$

16）前原孝光, 林 康史, 諸星隆夫他：I 期非小絗胞肺 籍にお计る sialyl-Lewis X 糖鎖抗原の発現と臨床 病理学的因子及び予後との関連. 日呼外会誌 $11: 517-522,1997$

17）工藤翔二, 日野光紀：肺癌の予後因子をめぐって。 痛と化療 $22: 827-835,1995$

18）阿部庄作：肺墰の分子生物学的予後因子. 日外会 誌 $98: 2-7,1997$ 


\title{
A CASE OF SOLITARY BRAIN AND SOLITARY LUNG METASTASES OCCURRED 13 YEARS AFTER AN OPERATION FOR ADENOCARCINOMA OF THE LUNG
}

\author{
Noriyuki TSUBOTA", Hideyuki TANABE", Ryohei HIGASHI", \\ Hiroko KUWABARA ${ }^{3 \prime}$ and Kiyohide TANIGUCHI" \\ "Department of Surgery. Kojima Central Hospital \\ 2'Department of Chest Surgery, Okayama National Hospital \\ ${ }^{3}$ Second Department of Pathology. Kagawa Medical School \\ "Department of Surgery. Takamatsu National Hospital
}

We have experienced a rare case of solitary brain and solitary lung metastases occurred 13 years after our operation that resulted in curative resection for a stage I lung cancer (adenocarcinona). A 74-year-old woman was admitted to the hospital because of attacks of unconsciousness and convulsions. Thirteen years prior to this admission. she had undergone a right lower lobectomy due to adenocarcinoma. $T_{1} \mathrm{~N}_{0} \mathrm{M}_{0}$, stage IA.

A solitary brain tumor shadow was detected on a brain CT and brain MRI. and a solitary lung nodular shadow was showed in the right lung field on a chest $\mathrm{CT}$. Both brain and lung tumors were resected and both were diagnosed histologically as metastasis of the lung cancer.

Immunohistochemical expression of PCNA and sialyl-Lewis X antigen (sLe) were examined for three operative specimens that were primary lung cancer, brain metasitasis, and lung metastasis. For all three specimens, the expressions of both PCNA and sLe ${ }^{x}$ were highly positive.

The patient with lung cancer that is highly expressive of PCNA and sLe $e^{x}$ would require a long-term follow up after operation for the primary lesion. 